Kaygl, 18(II)/2019: 351-373. Araştırma Makalesi | Research Article

Makale Geliş | Received: 07.05.2019

Makale Kabul | Accepted: 14.07.2019

Yayın Tarihi | Publication Date: 30.09.2019

DOI: $10.20981 /$ kaygi.612503

Banu ALAN SÜMER

Dr. Öğr. Üyesi | Assist. Prof. Dr. Kırıkkale Üniversitesi, Fen-Edebiyat Fakültesi, Felsefe Bölümü, Kırıkkale, TR Kırıkkale University, Faculty of Science and Letters, Department of Philosophy, Kirıkkale, TR

ORCID: 0000-0003-0047-6650

banu_felsefe@hotmail.com

\title{
Modern ve Postmodern Sanat Anlayışlarına Sanatçının Yeri Bağlamında Bir Bakış
}

$\ddot{O} z$

$\mathrm{Bu}$ makalede modern ve postmodern düşüncede sanatçının konumu ele alınmaktadır. Modernizm ile postmodernizm iki farklı düşünce sistemi olduğundan, onların sanat hakkındaki düşünceleri de farklıdır. Sanata olan bu farklı anlayış biçimleri, sanatçı hakkında da farklı görüşlere sahip olmalarına neden olmuştur. Makalede öncelikle modern düşüncedeki sanat algısına kaynaklık etmesi bakımından Platon ve Aristoteles'in sanat felsefesine ilişkin temel söylemlerine yer verilecektir. Daha sonra modern sanatın oluşumunda en büyük katkıyı yapan filozof olarak Kant'ın Yargıü̈cünün Eleştirisi adlı eserinde incelemiş olduğu deha konusu ele alınacaktır. Son olarak da postmodern sanatta ve edebiyat kuramlarında sıklıkla karşımıza çıkan bir konu olarak yazarın kim olduğuna, yazar-okur ilişkisine, yazarın ölümüne ve yazarın işlevine ilişkin tartışmalar, Foucault ve Barthes bağlamında ele alınacaktır.

Anahtar Kelimeler: Kant, Foucault, Barthes, Sanat, Sanatçı, Yazar, Deha, Yazarın Ölümü, Yazar-İşlevi.

\section{An Overview of the Place of the Artist in the Modern and Postmodern Understanding of Art}

\begin{abstract}
This article discusses the position of the artist in modern and postmodern thought. Since modernism and postmodernism are two different thinking systems, they have different ideas about art. These different forms of understanding of art cause them to have different views about the artist. In terms of being a source of modern art perception Plato and Aristotle's main discourses on philosophy of art will be included. Then, as a philosopher who made the biggest contribution to the formation of modern art, Kant's subject of genius that he probed in his work The Critique of Judgement will be discussed. Finally, the debates about the author, the author-reader relationship, the death of the author, and the author-function, a topic that is frequently encountered in postmodern art and literary theories will be discussed in the context of Foucault and Barthes.
\end{abstract}

Keywords: Kant, Foucault, Barthes, Art, Artist, Author, Genius, The death of the Author, The AuthorFunction. 


\section{Giriş}

Sanatta en çok tartışılan konuların başında, sanatçının sanat eserinde oynadığı rolün ne olduğu gelir. Felsefe tarihinde, kimileri Platon'dan hareketle sanatçının tanrısal esinlenme sonucu ürettiğini, sanatın böylesi bir yaratma olduğunu, kimileri Aristoteles geleneğinin bir devamı olarak sanatçının bir taklitçi, sanatın bir mimesis ve teknik bir etkinliğin ürünü olduğunu söyler. Kimileri de özellikle Kant'a atıf yaparak sanatçıların özgün yapıtlar ortaya koyan 'yaratan' dahi kişiler olduğunu belirtir. Bu çalışmada Aristoteles'ten günümüze değin süren bu tartışma ana hatlarıyla ele alınacak ve modern ve postmodern anlayışların sanatçıya bakışları ortaya konmaya çalışılacaktır. Modern sanat felsefesine ilişkin düşünceler açısından Kant, postmodern sanat açısından da Michel Foucault ve Roland Barthes'ın 'yazar'a ilişkin söylemlerine yer verilecektir.

Grek felsefesinde sanat ile zanaat arasında bir ayrım yoktu. Yunanca techne sözcügü, bir plana göre bir şey ortaya koyma amacıyla, pratiklik içeren beceri anlamında kullanılırdı. 'Platon, 'sanatlar'1, kazanıma dayalı, ayırıcı ve üretici sanatlara böler. 'Kazanıma dayalı sanatlar', sırası geldiğinde ya pratik amaçlar (örneğin ev yapma; genelde bu uygulama (b)ilimleri Aristotelesçi techne'ye tekabül eder) ya da theorik amaçlar adına kullanılabilecek bilgi kazanımını içerirler” (Peters 2004: 367). Bu anlamda techne sözcüğü sanat ve zanaat arasında bir ayrım yapılmaksızın, yarar amacı güdülerek yapılan işlerde gereken yetenek olarak anlaşıllyordu.

Eskiçağlarda karşılaşılan bu sanat ve zanaat özdeşliği, daha sonra güzel sanatlar kavramının ortaya çıkmasıyla, yani bir yarar amacı taşıyan nesnelerle, hiçbir çıkar gözetmeksizin, yalnızca hoşlanmak amacıyla seyredilmek için üretilen nesnelerin ayrılmasıyla ortadan kalkmıştır. Kant, Yargıgücünün Eleştirisi ile bir yandan sanat ile bilgiyi, bir yandan da sanat ile tekniği birbirinden ayırmıştır. "Sanat, insan becerisi olarak, bilimden de ayrıdır (yapabilmenin bilmeden ayrımı gibi), tıpkı kılgısal yetinin kuramsal yetiden, uygulayımın kuramdan (ölçme sanatının geometriden) ayrı olması gibi. Ve bu yüzden ne yapılması gerektiğini bilir bilmez ve öyleyse yalnızca istenen etkiyi yeterince tanır tanımaz yapabildiğimize de sanat denmez. Yalnızca birinin yapılacak olanı tam olarak bilse bile gene de bu yüzden hemen onu yapacak beceriyi 
taşımadığı zaman yapılan şey sanata aittir” (Kant 2006: 172). Yine Kant sanatın zanaattan ayrı olması konusunda şöyle söyler: "Sanat zanaattan da ayrılır; birinciye özgür denirken, ikinciye $\ddot{u} c r e t l i$ sanat da denebilir. Birinciye sanki ancak oyun olarak, kendi için hoş olan uğraş olarak ereksel çıkabilecek (başarılı olacak) bir şey gibi bakılır; ikincisi ise emek olarak, kendi için nahoş (zahmetli) bir uğraş olarak ve ancak etkisi (örneğin ücret) yoluyla çekici ve dolayısıyla zorla dayatılabilecek bir şey olarak görülür” (Kant 2006: 173). Kant'a göre, sanatın kendi dışında hiçbir amacı yoktur; onun tek amacı kendisidir.

Öte yandan Nietzsche’ye baktığımızda; ona göre sanat, bizi varoluşun acılarından ve kaygılarından kurtaran bir ilaç ve bir çare olarak ortaya çıkmıştır. Nietzsche'de sanat, felsefenin organonudur ve bu yüzden Nietzsche felsefenin merkezinde yer alır. Ona göre sanat bu dünyadaki en yüce etkinliktir. Çünkü sanat yaşama kendi başına olma olanağ1 verir. Yaşamı kendi gerçekliği yüzünden hiçliğe düşmekten kurtarır. Yalnızca sanat, hayatı mümkün kılan en büyük güçtür, yaşama götüren en büyük baştan çıkarıcı ve yaşamın büyük uyarıcısıdır (Nietzsche 2002: 421). Nietzsche'ye göre, sanat yapıtlarının etkisi, sanatçının ruh durumunu uyandırması ile ilgilidir. "Sanat özünde hayatı onaylamaktır, hayatı kutsamaktır, insan varlığının onaylanması, kutsanması, Tanrılaştırılmasıdır” (2002: 404). Sanatın en önemli etkisi, onun insan varlığını olgunlaştırarak, yetkinliği ve zenginliği meydana getirmesidir.

Sanat ürünlerinin doğal nesnelerden farklı oluşu, sanatın niteliğini de açığa çıkarır. Doğal dünyada gördüğümüz ve 'güzel' olarak algıladığımız nesne ve oluşumlar sanat eseri olarak kabul edilmez. Burada sanatın asıl özelliğinin, bir nesne üretmeyi amaçlamış olduğunu, bir tasarım sonucunda ortaya çıkan bir etkinlik olduğunu ve insanın yaratıcı gücüne bağlı olduğunu görürüz. Yine sanat eserini doğal oluşumlardan ayıran temel özelliklerin başında onun 'özgünlük' ve 'biriciklik' niteliklerine sahip olması gelir. Her sanat yapıtı, yaratıcısına özgü olarak biriciktir. Sanatın bu özelliği, sanatçının bakışından doğan 'tarz' kavramıyla da ilgilidir. Sanatçının özgünlügüünü oluşturan, onun kendine has tarzıdır. Tarz aynı zamanda sanatçıların sanata getirdiği yeniliklerdir. Dolayısıyla sanatın ayırtedici özelliklerinden en önemlisi 'yaratıcılık'tır. 
Özgünlük ve tarz kavramlarını birleştiren bu özellik, aynı zamanda sanat eserinin 'biricik olma' özelliğini de içerir. Bunu ortaya çıkaran da sanatçının yaratıcı kişiliğidir (Bozkurt 2014: 16).

Sanat yarar gözetici bir etkinlik değildir. “...güzel olduğunu söylerken ve bir zevkimin olduğunu tanıtlarken, onda nesnenin varoluşuna bağımlı olduğum şey ile değil, ama bu tasarımdan kendi içimde yaptığım şey ile ilgilenirim. Herkes kabul etmelidir ki, güzellik üzerine içinde en küçük bir çıkarın karıştığı yargı çok yanlı bir yargıdır ve bir arı beğeni yargısı değildir" (Kant 2006: 55). Kant'a göre beğeni, bir nesneyi ya da bir tasarım türünü hiçbir çıkar olmadan, bir hoşlanma ya da hoşlanmamaya bağlı olarak yargılama yetisidir. Böyle bir hoşlanmanın nesnesi de 'güzel' olarak adlandırılır. Croce de bu konuda benzer şekilde “...türü ne olursa olsun herhangi bir zevk, başlı başına sanatsal değildir. Susuzluğumuzu gidermek için içtiğimiz sudan aldığımız tat sanatsal bir öz taşımaz” (Croce 2009: 41) diyerek sanat eserinin verdiği zevki diğer zevklerden ayırır. Dolayısıyla beğeni yargımızın nesnesi olan 'güzel', her türlü çıkardan soyutlanmış olmalıdır.

Sanat, yaşamın yansıtılış şekillerinden en önemlisidir. Bir sanat yapıtı, döneminin tininin bir ürünüdür. Bu bakımdan o dönemin tarihsel koşulları, felsefi, bilimsel, dinsel düşünüş şekilleri, ahlaksal, hukuksal, siyasal düzeni ve yaşama stilleri anlaşılmadan sanat yapıtı anlaşılmaz. Sanatçıda tüm bunların izleri vardır. Tüm bunlar alımlayıcıyı da sanatçıyı da sarar ve alımlayıcının yapıtı anlamasının olanağı da sanatçı ile aynı ortak tin içinde yer almalarından gelir. Başkalarını ancak birlikte yaşadığımız ortak zemin sayesinde anlayabiliriz. $\mathrm{Bu}$ ortak zemin içerisinde sanat, yaşamayı anlamada başvurulacak temel kaynaktır (Özlem 2007: 24).

Sanata ilişkin bu genel tanım ve belirlemelerden sonra, yukarıda sözü edilen filozoflar bağlamında sanatçının felsefe tarihi içindekinin yerinin ne olduğuna bakabiliriz. 


\section{Antikitede Sanat: Mimesis mi Poiesis mi?}

Platon'un sanat ve sanatçı üzerine düşünceleri daha çok ideal devletin içindeki yeri bağlamında ele almıştır. Platon'a göre, sanatçılar, yapıtlarını, bir ilham ve bir kendinden geçiş hali ile ortaya koyarlar. Burada mimesis anlamında bir teknik etkinlikten çok, poiesis anlamında bir yaratma etkinliği söz konusudur. "Poiesis (yaratma) fikri, çok kapsamlı bir fikirdir. Çünkü, yokluk'tan varlık’a geçiş, hangi halde olursa olsun, poiesis'tir; dolayısıyle, bütün alanlara ait sanat eserleri poiesis'tir ve bunları yapan bütün sanatçılar da poietes'tir'. (Platon 2000: 72). Platon'da sanat poetik bir etkinliktir yani yaratma ile ilgili bir etkinliktir. Platon sanatçı ile, yani ruhunda yaratma gücü taşıyan kişi ile güzel arasında bir ilişki kurar. Buna göre sanatçının ereği, güzel ile kucaklaşmaktır. Burada güzel, bedenden başlayarak sırasıyla ruh ve erdem güzelliğinden geçerek, 'kendi başına güzel'e ve öz güzelliğe yükselir. Bu en yüksek güzele ise ancak buna yeteneği olan kişiler, yani sanatçılar ve filozoflar ulaşabilir (Tunalı 2004: 70). Böylece sanatın yaratıcılığı ancak güzelde kendini bulur ve sanatın anlamı da ancak sanat yapıtında ortaya çıkar.

Platon'da sanatsal etkinliğin poetik bir etkinlik olarak görülmesi, sanatın bir mimesis (taklit) etkinliği olmadığı anlamına gelir. Ancak Platon, sanatçının yaratıcı etkinliğini önemser gibi görünse bile gerçekte bu böyle değildir. Çünkü sanatçının yaratıcılığı kendinden kaynaklanmayan bir yaratıcılıktır. O, tanrıların aracı olarak görüldüğünden, söyledikleri de kendine ait değil, tanrılara aittir. İdeaların bir kopyası olan görüngüler evreninde, sanatçının etkinliğgi, taklidin taklidi olarak görülür. Platon sanatçıyı Aristoteles’ten daha düşük bir statüye yerleştirir ve onun, gerçekliği tam olarak taklit bile edemediğini belirterek, sanatçıyı ideal devletinden kovar (Özlem 2007: 8). Şölen diyaloğunda poetik bir etkinlik olarak anlaşılan sanat, Devlet adlı kitapta kendisine pek yer bulamamış, daha çok mimesis dolayımında ele alınmış ve hatta çoğu zaman toplum için zararlı bir etkinlik olarak görülmüştür. Böylece Platon poesis olarak sanat etkinliği üzerinde fazla durmamış ve bu görüşünü sistematik bir biçimde geliştirmemiştir. 
Neredeyse Grek dünyasının tamamına yayılan bir görüş olarak mimetik sanat anlayışının ne anlama geldiğinin tek bir tanımı olmasa da, o, çoğunlukla taklit veya taklit etme üzerine kurulu bir sanat görüşünü ifade eder. Platon'un mimesis’ten söz etmesinin ve sanatı bir taklit olarak görmesinin ardından, onu bir sanat teorisi haline getiren filozof Aristoteles'tir. Aristoteles, Poetika'da, sanatsal etkinliği, ussal açıdan irdelemiş ve dünyadaki doğal düzen ile sanat yapıtının, hem oranları hem de birliği bakımından bir kurala uyması zorunluluğu arasındaki bağıntı üzerinde durmuştur.

Aristoteles'e göre, genel olarak sanatı ve özel olarak edebiyatı ve onun en gelişmiş örneği olarak tragedyayı karakterize eden yön, onların belli kurallar doğrultusunda belli türden bir etki yaratmak amacıyla gerçekliği taklit etmeleri, yani mimesis etkinlikleri olmalarıdır. "Epos, tragedya, komedya, dithyrambos şiiri ve flüt, kithara sanatlarının büyük kısmı taklittir" (Aristoteles 2017: 35). Ad1 geçen bu sanatların yanı sıra, biçimsel sanatlar da taklit edicidir. "Şair de aynı ressam gibi ya da biçim verici herhangi bir sanatçı gibi taklit eden bir betimleyicidir” (2017: 85). O, en üstün edebi tür olarak gördüğü tragedyada amacın, katharsis olduğunu, korku ve acıma duygularını uyararak ruhu tutkulardan arındırmak olduğunu belirtir. Aristoteles techne ile sanatsal bir etkinliği, gerçekliği taklit ederek oluşturulan teknik bir etkinliği ifade eder. Ona göre, taklit bir yaratıcılık kaynağı ve bir duygu olarak, hem insan varlığına yerleştirilmiştir hem de insanın temel bir belirleyicisidir. Taklidin bir insanın ana özelliği ve insana özgü doğuştan ve temel bir duygu olarak ve tüm insan bilgisinin ana motifi olarak görülmesi, insanın meydana getirdiği her şeyin temelinde mimesisin olduğu anlamına gelir. Platon mimesisi olumlu bir etkinlik olarak görürken, Aristoteles onu insan doğası içine koyarak, tüm bilgimizi sağlayan bir motif olarak anlamaktadır (Tunalı 2004: 99). Sanatçı doğrudan doğruya gerçekliğe yönelip onları taklit eden bir taklitçidir. Böylece Aristoteles yüzyıllar boyunca etkili olacak sanat anlayışının temellerini atmıştır.

Ancak Aristoteles'te mimesisin kaba ve gündelik anlamda bir taklit anlamına gelmediğini de belirtmemiz gerekir. Bunun nedeni, mimesisin sadece taklidin tek belirleyicisi olan gerçeklik kategorisi tarafından belirlenmemesidir. Mimesis bir sanat 
etkinliği olarak yalnızca olana değil, olması gerekene de yani ideal olana da yönelebilir. (Tunalı 2004: 106). Mimesisin ideal olana yönelmesi, gerçek üzerinde bir düşünme etkinliğini gerektirir ki bu da sanatçının bu etkinlikteki önemini ifade eder. Sanatçılar, kendi öznelliklerini katarak realitede karşılığı olmayan sanat eserleri üretebilirler.

Aristoteles' in bu görüşleri ile sanatçı önemli bir konuma gelmiş olsa da Grek dünyasında sanatçının yerinin genelde ikincil bir konuma yerleştirildiğini söylemek gerekir. Aristoteles'in sanatın ereğini moral bir erek olarak belirlemesinin de bunda etkisi vardır. Ona göre, sanat estetik bir hoşlanma için değil, moral bir değer için belirlenir ve bu moral değer, katharsis sürecinde nesnelleşir. Sanatın görevi insanda estetik haz uyandırmak değil, etik bir haz uyandırmaktır. Aristoteles sanatsal etkinliği, ahlaki etkinlik ile ilişkili olarak ele almış ve sanat, etik karşısında bağımsızlığı olmayan ve hatta ahlakın hizmetinde olan bir alan olarak görülmüştür. Sanatçının görevi de bu ahlaksal durum çerçevesinde, katharsis etkisi uyandırmak olmalıdır (Tunalı 2004: 116). Sonuç olarak sanatçı, kendi özgür edimiyle yaratan bir kişi olmayıp, görevi ahlaka hizmet etmek olan, sanatını etik olana uygun bir biçimde icra eden kişi olarak görülmüştür.

Platon'un ve Aristoteles'in sanatçıya ilişkin düşünceleri, genel olarak 18. yüzy1la kadar yaygın bir kabul görmüştür. Descartes ile birlikte özneyi merkeze alan düşünce sisteminin karşısında, Platon ve Aristoteles'in nesneyi merkeze yerleştiren söylemleri gerilemeye başlamış, sanata ve sanatçıya verilen önem de artmıştır. Sanatçıya artık bir taklitçi olarak bakmak reddedildiği gibi, sanatçının tanrısal güçleri kullanan edilgin bir aracı olduğu görüşü de reddedilmiştir. Evrenin merkezine tanrıyı veya doğayı koyan, insanı tanrısal veya doğal bir belirlenim altına yerleştiren eski anlayışın yerini, evrenin merkezine insanı koyan, onu özne sayan anlayış almıştır. Modern özne, toplum içinde edilgin konumda olan bir özne olmayıp, toplumu diğer öznelerle birlikte kuran ve birlikte yöneten etkin bir öznedir (Özlem 2007: 9). Böylece bu etkin öznenin artık sanatsal etkinlik sırasında bir taklitçi veya edilgin bir aracı olarak görülemeyeceği açıktır. $\mathrm{Bu}$ dönemde sanatçı; yaşadığı dünyaya biçim veren, yaratan kişidir. Sanat 
etkinliği de, bir biçim verme etkinliği olarak sanatçının iç dünyasıyla ilgili bir etkinliktir.

Sanatçıya tanınan bu konum ile ilkçağdan 18. yüzyılın başlarına kadar devam eden, sanatçılığı arka plana atan, sanatçıların ve yazarların bireyselliklerini önemsemeyen ve onları aracı olarak gören anlayış tamamen silinmiştir. Sanatçıyı yaratıcı olarak görmeyen anlayışın karşısında, onu dâhi ile özdeşleştiren görüşler ortaya çıkmış, bu konuda Kant'ın dehâ estetiği önemli bir dönüşüme yol açmıştır.

\section{Kant ve Dehânın Yaratımı Olarak Sanat Yapıtı}

Kant'a göre yaratıcılığın kaynağı sanatçının dehâsıdır. Zanaat ve sanat ayrımını da dehaya dayandıran Kant için, zanaat mimesise dayalı bir etkinlik iken, sanat yaratıcılıkla özdeşleştirilen dehaya ait bir etkinliktir. Kant ve onun izinden giden Schelling için sanat yapıtı, dâhinin (sanatçının) bir defalık yaratısı olarak, bilinçsiz bir yaratmanın ürünüdür. Schelling'e göre, Dahi sanatçı, kendisindeki otonomiyi bilmeksizin sürekli yaratır (Schelling 2016: 68). Yani dâhi (sanatçı) herhangi bir kural olmaksızın ve bilinçsizce yapıtını yaratır. Sanat eseri bir deha ürünü olarak, dahi sanatçının yaratıcı kişiliği sayesinde kendi yasasını koyduğu bir etkinliğin sonucudur ve ürünüdür. Kant bunu şöyle ifade eder:

“...güzel sanat kendi kendisine ürününü ona göre ortaya çıkaracağı kuralı uyduramaz. Şimdi, ön bir kural olmaksızın bir ürüne hiçbir zaman sanat denemeyeceği için, doğa öznede (ve onun yetilerinin uyumu yoluyla) sanata kural vermelidir, güzel sanat, ancak deha yoluyla olanaklıdır" (Kant 2006: 177).

Kant, estetiğe asıl yerini kazandırmış, 'güzel'in kesin sınırlarını çizmiştir. "Kant beğeni yargısının öznel bir temele, yani hoşlanma ya da hoşlanmama duygusuna dayanmasına karşın, bu yargıya bir genellik yüklemiştir. Başka deyişle, beğeni yargısını genel bir yargı olarak temellendirilmek istemiştir. Burada, beğeni yargısının genelliği, nesnel bir genellik değil, öznel bir genelliktir” (Bozkurt 2014: 146). Doğa ve ahlak alanında aprioriyi arayan Kant, estetik alanında da aprioriyi arayarak, estetik yargılara bir genel geçerlik kazandırmayı amaçlamıştır. 
Kant'a göre, sanat yapıtındaki kendine özgü kural ve düzen, yaratıcı etkinlikten kaynaklanır. Dehânın kendisi dıştan hiçbir kurala bağımlı değildir; onun kendisi bizzat kuralın kendisidir. Dehâda bir iç yasalılık ve ereklilik, gizli halde zaten vardır. İşte bu, somut ve tek bir sanat yapıtında kendini gösteren ve biçim almış olan şeyin kendisidir (Cassirer 2007: 427). Güzel sanat ürünleri, dehânın ürünleridir. "Dehâ yetenektir (doğa vergisi) ki, sanata kural verir. Yetenek, sanatçının doğuştan üretken yetisi olarak, kendisi doğaya ait olduğu için, bu şöyle de anlatılabilir: Deha doğuştan anlak yatkınlığıdır (ingenium) ki, doğa, sanata kuralı onun yoluyla verir” (Kant 2006: 176).

Dehâ öyle bir yetidir ki, ona belirli hiçbir kuralın verilmesini istemeyeni üretir, o, herhangi bir kurala göre öğrenilebilen bir beceri değildir. Bu yolla özgünlük onun ilk özelliği olmaktadır. Dahi sanatçı, ürününü nasıl ortaya koyduğunu kendisi betimleyemez veya bilimsel olarak belirtemez, ancak doğa gibi kural verir. Sanatçı ürününü yaratmasını dehasına borçludur, ancak kendisi bunun farkında değildir. Deha bir insana doğumuyla birlikte verilen ona özgü koruyucu ve yol gösterici tin olarak 'genius'tan türetilmiştir ve o özgün düşünceler onun esininden gelmiştir. Doğa deha yoluyla bilime değil, ama sanata kural verir ve bunu da ancak onun güzel sanat olacağ1 düzeye de yapar (Kant 2006: 177).

Kant'a göre, 'estetik yargılar' 'dehâ' ile 'sanat yapıtı' arasındaki ilişkide ortaya çıkan yargılardır ve estetik ideler, usun idelerinden ayrıdır. Kant'ın estetik idelerle kastettiği, duyulara ve algılara dayanan hayal gücünün tasarımlarıdır. Estetik ideler, usun bir kavramı değil, hayal gücünün tasarımlarıdır. Hayal gücünün yaratıcılığıyla harekete geçen ideler kavranamaz bir dünyanın tasarımlarına dönüşürler. Burada dehâ'ya özgü olan şudur: 'Verilmiş bir şeyin kavramında ide'leri bulmak ve buna somut biçimde dille ya da görsel- işitsel olarak- ifade kazandırmak’ İşte burada Kant'a göre, 'aynı zamanda yeni bir kural getiren, yeni bir biçim ortaya koyan ve özgün olan şey 'Tin'(Geist)dir (Bozkurt 2014: 156). Buradan da anlıyoruz ki, sanat doğanın taklit edilmesinden ibaret değildir. Sanat varolandan yeni şeyler ortaya çıkarma ve verili olanı yeniden biçimlendirme amacıyla yapılan bir etkinliktir. 
Kant, beğeni yargılarının öznel bir ilkesi olması gerektiğini düşünür. Bu ilke, bir şeyin hoşa gidip gitmediğini genel geçer olarak belirleyen bir ilkedir. Kant için beğeni yargılarının dayandığı ilke 'ortak estetik duyu (sensus communis aestheticus)'dur. Bu ortak duyu sayesinde Kant beğeni yargılarını görelilikten kurtarıp, bir kesinliğe oturtmak istemiştir.

"Şu tablo güzeldir, dediğim zaman, bu beğeni yargısı, sanat yapıtı dediğim 'tablo' karşısında, yalnız benim özel olarak duyumsadığım bir hoşlanmayı dile getirmez, ama aynı zamanda o, herkes için geçerli, zorunlu bir yargıdır da. Bunun için 'güzel' dediğim o tabloyu, herkesin 'güzel bulmasını isterim ve bunu da herkesten beklerim; çünkü 'şu tablo güzeldir' yargısına, bu ortak duyuya dayanarak varırım” (Kant 2006: 95).

Kant'a göre bu ortak duyu, tek tek beğeni yargılarının ölçütüdür. Her tekil beğeni yargısı, bu tümel beğeninin nesnelleşmesidir. Ona göre bu ilke bütün insanlarda vardır ve beğeni yargılarının genel geçerliği, herkesin ortak olduğu bu duyuya dayanır. Ancak estetik beğeni kişiden kişiye değişen, öznel bir beğenidir. Dolayısıyla estetik yargıların evrenselliğinden ve genelliğinden söz edilemez. Her insanın ve her kültürün farklı bir beğeni tarzı, farklı bir alımlama gücü, farklı bilgi birikimi ve farklı bir yorumlama düzeyi vardır.

Kant, Lessing'in bir dehanın ancak yine bir dehadan etkilenebileceği görüşünü şu sözlerle dile getirir. "Sanatçının ideleri öğrencisinde de benzeri ideleri uyandırır; eğer doğa onu da (öğrenci) ruh güçlerinin benzer bir orantısı ile donatmışsa" (Cassirer 1996: 345). Bu orantı dehanın yaratıcılığındaki özgül motifi belirtir. Bu açıdan bakıldığında, sanatsal üretim, bilimsel üretimden de ayrılır. Kant, deha kavramını sanat ile sınırlandırmıştır. Büyük bir bilim adamının keşfinde de dehadan bir şeyler vardır. Ancak o bilim adamı keşfinden dolayı dahi olarak adlandırılmaz. Kant bunu şöyle ifade eder:

\footnotetext{
“Çünkü (onun bulduğu şey) tam da öğrenilebilir bir şey olduğundan dolayı. Çünkü o, araştırmanın doğal yolu ve yöntemli düşünme ile bulunmuştur. Ve taklide dayalı bir çaba ile kazanılmış olan şeylerden özel olarak ayırdedilemez", "Newton'un doğa felsefesinin ilkelerini içeren ölümsüz yapıtlarında ortaya konulmuş ne varsa, rahatça öğrenilebilir. Ama şiir yazmak öğrenilemez; şiir sanatı üstüne tüm kurallar ne kadar bilinmiş olsa,
} 
bu konuda örneklere başvurulsa da, Newton'un geometrinin ilk öğelerinden başlayıp büyük ve derin buluşlarına varıncaya kadar atmış olduğu tüm adımlar, yalnızca kendisi tarafından değil, tersine herkes tarafından tam olarak izlenebilir, Ama Homeros veya Wieland'ın fantezi yüklü ve aynı zamanda düşünce dolu idelerini kafaları içinde nasıl oluşturup bunları biraraya getirdikleri asla gösterilemez. Çünkü onlar bunu nasıl yaptıklarını kendileri de bilmezler ve demek ki başkalarına da öğretemezler. Oysa bilimde bir kaşif, pek büyük çaba gösteren bir taklitçi ve çömezden ancak bir derece farkıyla ayrılır. Ama buna karşılık o, doğanın güzel sanat için bağışta bulunduğu kişiden kesinlikle ayrılır” (akt. Cassirer 2007: 431-432).

Kant'ın bu yeni sanatçı tanımı, sanatçının bireyliğini ve yapıtının bir defalığı ile özgünlügüün̈ vurgulaması, sanat eserini sanatçının kendisinin bile bilincinde olmadığı kurallara bağlı olarak ortaya konulan bir ürün olarak görmesi estetik alanında yeni bir sayfa açmış, sanat yapıtının anlaşılması konusunda da birtakım zorlukları beraberinde getirmiştir. İlkçağların mimesis anlayışında, sanat yapıtının anlaşılması konusunda bir zorluk yoktu. Çünkü sanat yapıtı taklit amaçlı bir teknik çalışmanın, bir çeşit zanaatkarlığın ürünüydü ve yapıtın niteliğini de teknik ölçütlere göre belirlemek mümkündü. Oysa şimdi Kant ile birlikte sanat yapıtı bir özerlik kazandığından, yapıtın nasıl anlaşılacağı bir sorun olarak ortaya çıkmıştır.

Bu noktada Heidegger'e bakarsak, onun Sanat Eserinin Kökeni adlı yapıtında, sanat, sanatçı ve sanat eserini karşılıklı bağları içinde ele aldığını, sanatın özünün sanat yapıtı aracılığıyla ortaya çıkacağını vurguladığını görürüz. Ona göre varlığın gizlisiz saklısız yanı sanat yapıtına gelip yerleşir ve hakikat de sanat yapıtında görülür. Sanat, içinde hakikatin ortaya çıktığı yollardan biridir (Heidegger 2007: 52). Heidegger'e göre, sanat yapıtı yaratıcısına bağlıdır, ama aynı zamanda yaratıcı kişi de sanat yapıtına dayanır. Sanatçı ile yapıtı arasında karşılıklı bir bağımlılık söz konusudur. Her ikisi de sanatın kendisinden çıkarlar. Sanat yapıtının kaynağı sanatın kendisidir. Sanat kavramı, sanat yapıtı içinde Hakikat'in yaratıcı bir biçimde saklanması ya da korunmasıdır. Bu koruma ya da saklama yapıtın alımlayıcıya ulaşması ve onda yarattığı izlenimle ilgilidir (Bozkurt 2014: 291).

Aristoteles'in kuramında sanatçıya biçilen rol onun sadece taklit yapması sebebiyle çok düşükken, Kant sanatçıları deha ile özdeşleştirmiştir. Burada önemli olan 
bakmayı, görmeyi bilmektir. Sanatçının önemi onun bakışıdır, hayalgücü, duyarlılığı ve duygululuğudur. Sanatçı doğada gördüklerini aynen taklit eden kişi değil; görüşü, ifade edişi ve anlatışı ile ona yeni bir biçim verendir. Böylece sanatçıyı sadece yansıtan olarak değil, yaratıcı olarak da görmek gerekir.

\section{Postmodernizm ve Sanat}

1970’lerden itibaren bir takım kültürel ve eleştirel hareketlerde yaygın bir biçimde kullanılan Postmodernizm kavramının tek bir tanımını yapmak oldukça güçtür. Postmodernizm ancak modernizm ile ilişki kurularak anlaşılabilir. Modernizmde ilerlemeye ve yeniliğe tam bir inanç söz konusu iken, postmodernizm bu düşüncelerin bir sorgulamasını ve eleştirisini içerir. Modernizm sanat ve popüler kültür arasında net bir ayrım olması gerektiği konusunda 1srar ederken, postmodernizm kültürün ve sanatın herhangi bir biçimine işaret etmez. Tam tersine o, bir çoğulculuk ile ilişkilendirilerek, özgünlük ve yazarlık konusunda geleneksel düşüncelerin terkedilmesi gerektiğini öğütler. İnsan merkezli bir düşünce sistemi olarak modernizmde Kant'ın da etkisiyle akıl temel bir ölçüttür ve insanın aklı sayesinde her şeyi öğrenebileceği fikri esastır. Postmodernizmde ise, hakikati ya da dünyayı anlamada tek bir ölçüte başvurulmaz, çünkü postmodernizmde evrensel ve değişmez bir hakikat anlayışı söz konusu değildir. Modernizmin aklı yücelten tavrı karşısında Jacques Derrida, Michel Foucault ve Roland Barthes gibi düşünürler, tek bir merkezi esas alan modernist düşünceye bir takım eleştirler getirerek, dil, siyaset ve edebiyat alanında postmodernist düşünceyle örtüşen bir takım fikirler öne sürmüş, metinlerin aslında çok yönlü ve farklı şekillerde okunabileceğini göstermişlerdir.

Postmodern düşünürlere göre batı dünyası tanrı merkezli ortaçağın bitimi ve insan merkezli Rönesans ve hümanist yaklaşımların başlangıcından beri yüzyıllardır dünyayı ve yaşamı us yoluyla tanımlamaya çalışmışlardır. Postmodernizme göre, toplum, sanat, dil ve bilim hem insanoğlu tarafından oluşur hem de onu oluşturur. Derrida, Foucault, Barthes, Lyotard ve Baudrillard gibi düşünürler modernizmin temelindeki insan merkezli kuramları böyle bir yaklaşımla inceleyip, modernist yaklaşımın insan ve us 
merkezli bir gerçeği yansıtmasının yanlışlığını dile getirmeye çalışırlar. Postmodern düşünürlerin de topluma, bilgiye, gerçeğe ve insana bakışları elbette birbirinden farklıdır. Ancak ortak oldukları nokta; insanı modernistlerin yaptığı gibi evrensel nitelikli, benzer us ve algılara dayalı olarak ele almamalarıdır. Onlara göre insan sürekli bir oluşum ve gelişim içindedir ve o yaşadığı dünyayı kendisi kuran ve kurduktan sonra da ona biçim veren bir varlıktır.

Derrida için metin, başı ve sonu tek bir tema üzerine kurulu, bütünlüklü bir yapı olarak görülmez. Metin farklardan oluşur ve bu da onun heterojen olmasına neden olur. Metnin heterojenliği, onun kendi başına bütünlüklü bir yapı olmasını engellediği gibi, metnin başka anlamlara da gönderme yapmasına olanak tanır (Derrida, 1981: 25). Dolayısıyla Derrida’ya göre, metnin anlamı sabit olmayıp, içinde çelişkileri ve belirsizlikleri taşır. Bu yüzden metnin anlamı için, sadece yazarın ne söylediğine değil, metinde olmayana, söylenmeyene de bakmak gerekir. $\mathrm{Bu}$ da yazar karşısında okuyucuyu öne çıkaran bir okuma edimidir. Foucault ise, bilgi ile politik güç arasındaki ilişki üzerinde durduğu yazılarında, her söylemin ve epistemolojinin belli bir politikanın ürünü olduğunu ve onun düzenini ve değerlerini sürdürmeyi amaçladığını söylemiştir. “ $\mathrm{Bu}$ nedenle görüşlerini ancak mevcut söylemlerin dışına çıkarak aktarabileceğini düşünen Foucault, yazılarında ve söyleşilerinde sık sık tutuklu dili, delilerin dili gibi hakim düzence kabul görmeyen sözcük ve kavramları kullanır” (Doltaş 1999: 28). Ona göre, gücü elinde bulunduran bürokrasiler tarafından üretilen söylem ve düşünce sistemleri hakimiyetini korumuş, bunların dışındaki söylemler ise bastırılmıştır. Bu görüşleri ile Foucault, modernizmin merkeziyetçi düşünüş biçiminin karşısında yer alarak, çoklu bir anlam anlayışını savunmuştur. Barthes da eserlerinde fotoğraf, yazın metni ve müzik konularını postmodern bir tarzda ele almıştır. Ona göre sanat ürünleri, bilgilendirme amacıyla hazırlanan ürünlerden farklı değildir. Herhangi bir sanat eserinin Kant'ın belirtmiş olduğu özellikleri taşıyıp taşımaması ancak onu algılayan özne tarafından belirlenir. Sanat eseri ile onu tanımlayan özne birbirinden kopuk değildir; özne nesneyi belirlerken kendi özelliklerini de ona aktarmış olur (Doltaş 1999: 30). Anlamın sanatçı ve onu algılayan özne arasında karşılıklı olarak üretilmesi konusunda 
benzer düşünen Foucault ve Barthes, metnin yazarı ve okuru arasındaki ilişkiye de yeni bir soluk getirmiştir.

\section{Roland Barthes ve Yazarın Ölümü}

Fransız göstergebilimci, edebiyat eleştirmeni ve kültür kuramcısı olan Roland Barthes (1915-1980), bir sanat eserinin kendisini oluşturan kültür bağlamında yeni bir fikir ve anlam ortaya çıkardığını söyler. Yazarın Ölümü adlı çalışmasında, metinsellik ve yorumlama ile ilgili önemli düşünceler öne sürmüş; yazar, edebi yapıt, anlam ve okumaya ilişkin yerleşik düşüncelere karşı bir takım eleştiriler yöneltmiştir. Barthes öncelikle edebi eserlerde yazarın ayrıcalıklı bir konumu olduğu fikrine karşı çıkar, bunu reddetmekle o, metinde birincil bir anlam olduğu fikrine de karşı çıkmış olur. Ona göre metnin anlamını belirleyen şey yazarın niyeti değil, metnin başka metinlerle olan ilişkisidir.

Barthes'ın düşüncesini anlamamızda önemli kavramlardan biri olan metinlerarasılık kavramı, her metnin başka metinlerle diyalog halinde olduğunu ifade eder. Barthes'a göre, her metin göndermeler yoluyla daha geniş bir anlam bağlamı sağlayan büyük bir metinler alanının parçasıdır. Bunun sonucunda anlam sadece yazarın niyetine veya otoritesine bağlı olarak değil, okur, metin ve metnin öne sürdüğü daha geniş kavramsal ağlar arasındaki ilişkiye bağlı olarak üretilir (Hitchcock 2013: 105). Modern düşüncenin varsaymış olduğu anlam hiyerarşisi karşısında duran Barthes, okurun doğuşuyla birlikte artık sadece bazı anlamların daha derin olduğunu ve bazı temel anlamların var olduğunu gündeme getirmiştir. Ona göre "okuyucunun doğumu yazarın ölümü pahasına gerçeklemelidir” (Barthes 1977: 148. Böylece Barthes yazarın otoritesini yerinden ederek, onun ölümünü ilan etmiştir.

Yazarın ölümü ile Barthes bir sanat eseri de dahil olmak üzere herhangi bir metnin çokanlamlılığını ve kendi kültürel bağıyla birlikte okuma gerekliliğini ifade etmiştir. Örneğin hermeneutik bir okumada olduğu gibi, onu yazıldığı dönemin şartlarından, toplumun yapısal özelliklerinden bağımsız olarak okuyamayız. Metne 
bütünsel bir bakış gerektiren bu düşünce, anlamlama (signification) dizgelerinin tümünü dikkate almayı önerir. Barthes’a göre, metnin başında yazar ölmüştür ve artık yazı yazarın ürünü olarak algılanmamaktadır. (1977: 145,146). Burada Barthes, okuyucuyu öne çıkararak, metinde yazarın amacına ilişkin bir tartışmayı da başlatmış olur. Acaba metin yazarın kendi niyetini yerleştirdiği bir anlamdan mı ibarettir? Yoksa okuyucunun doğuşu ile tüm anlam okuyucuya bağlı olarak bir çokanlamlılık mı taşımaktadır? Yazar-okur ilişkisine dair bu tartışmalarda Barthes, geleneksel görüşlerin aksine metinlerin tek ve sabit bir anlam taşımadığı görüşünü savunur.

Barthes'a göre, yazar, orta çağın sonunda İngiliz ampirizmi, Fransız rasyonalizmi ve Reformasyonun kişisel inancıyla toplumumuz tarafından üretilen modern bir figürdür. (1977: 143). Modern düşüncede yazar, yazının merkezini belirlerken, postmodern okur metne sonsuz anlamlar yükler. Modern yazar metni sınırlandırırken, post modern okur metni özgürleştirir. Yazarın ölümünden söz ediliyorsa sabit bir anlam da ortadan kalkmış olur. Metni yazara bağlamak, sürekli bir otoriteye bağlı olarak bir gerçekliği anlamak yanlış bir okumadır. Yazının okuyucu ile anlam bulmasını varsaymak gerekir. Modern metinlerin özelliklerinden biri, metnin gizli bir anlamı okuyucuya iletmesidir. Okur metindeki bu gizli anlamları ve yazarın niyetini bulmaya çalışır. Anlam okurun etkinliğine bağlı olarak oluşuyorsa, o halde çoklu bir anlamlama dizgesi mevcuttur. Böylece her bir metin, gösterenlerin serbest dolaşımı yoluyla anlam üreten birer bütünlüktür ve yine her bir metin gösterenlerin bir oyunundan ibarettir. $\mathrm{Bu}$ da, anlamın bu metin dışında başka bir şeye ertelenmesidir. Yani aslında her okur metni yeniden yazandır. Yazarın okurdan farkı onu yazmış olmasıdır.

Barthes'a göre “bir metne bir yazar vermek o metne bir sınır koymak, onu nihai bir gösterilen ile sunmak, yazıyı sonlandırmak anlamına gelir” (1977: 147). Ona göre farklı yorumların ve anlamların bulunması yalnızca farklı sosyal ve kurumsal bakış açılarına sahip farklı okurlardan kaynaklanmaz. Bundan daha da önce bir gösteren olarak sözcüklerin ve diğer gösterenlerin sabit olmayan, değişen anlamları vardır. Sözcükler sabit değildir, çünkü onlar ancak diğer sözcüklerle ilişkileri bağlamında bir anlam kazanırlar ve dilbilimsel gösterge, nedensiz, ayrımsal ve ilişkiseldir. Metnin ne 
anlama geldiğine dair çok sayıda ve birbiriyle yarışan yorumlara neden olan da göstergenin özünde var olan bu değişkenliktir. Böyle bir gösterge anlayışı anlam konusunda geleneksel görüşe bir karşı çıkıştır, çünkü bu anlayış, gösteren ile dışsal ve sabit bir anlam olarak gösterilen arasında birebir bir ilişki olduğu fikrini reddeder (Hitchcock 2013: 107). Herhangi bir çalışmanın anlamlandırma etkinliği içerisinde bir anlam kazanması o çalışmanın göstergelerinin yer değiştirmesi ya da dönüştürülmesinden başka bir şey değildir. Göstergeler evrensel kodlarla belirlenmiştir ama göstergelerin yer değiştirmesi mümkündür. Barthes, yapısalcılığı dilbilimcilerin yöntemlerinden kaynaklanan kültürel ürünleri çözümlemenin bir yolu olarak tanımlar. "Yapısalcı bir çözümleme bir metnin bir "açıklama"sını sağlamaz; bunun yerine, metnin ilk görünümünden işe başlar ve sorumlu olan kodların yerleşimine girer, "terimleri tanımlar, sıralamalarını belirler, ama aynı zamanda ilk kodların perspektifinde görünecek olan diğer kodların gerçekliğini de varsayar" (Culler 2008: 94). Yazar, bir göstergenin veya bir idenin her zaman dil içerisindeki anlamlarından birisini kullanmıştır. Bu bakımdan yazarın yaratıcılı̆̆ seçmiştir. "Bir metnin bir sözcük satırından oluşmadığını, tek bir "teolojik" anlamı (Yazar-Tanrı'nın “mesajı”nı yayınladığını) değil, çeşitli boyutlarda tartışıldığı ve tartışıldığ 1 birçok boyuttan oluşan bir alan olduğunu biliyoruz. Metin, kültürün sayısız merkezlerinden kaynaklanan bir alıntı dokusudur.” (Barthes 1977: 146). Böylece her metin, dilin yapısı ve metinlerarasılık sebebiyle bir anlam hareketliliği taşır.

Metnin anlamı için yazara başvurmak kişinin yorumuna meşruiyet kazandırmaya yarar. Yazarın otoritesi birincil kılındığı sürece başka hiçbir yoruma izin verilmez ve diğer yorumlar dikkate alınmaz. Yorumu yazar merkezli bir okumanın kısıtlılığından kurtarmak için, yazarı simgesel olarak öldürmek gerekir. Yazarın ölümü, metnin metinlerarasılık zemininde ele alınması ve okuyucunun bir yorumcu olarak daha yüksek bir seviyeye taşınması anlamına gelir. Böyle yapıldığı takdirde, okur, metni yazarın niyetinden bağımsız olarak yorumlamakta özgür olur ve yazar karşısında ayrıcalıklı bir konum kazanır (Hitchcock 2013: 106). 
Yazarın ölümü ile yazı birden çok gösterilene bağlandığı için, anlam alışılmış olanın dışında anlaşı1ır. Yani bu düşünce ile artık yazıda herkesin aynı anlamı görmesi mümkün değildir, aynı anlam görülemez çünkü artık bir anlam çokluğu söz konusudur. Farklı anlamların oluşu ve anlamın sabitlenemez oluşu Barthes'ın post yapısalcı yönünü gösterir. Barthes'ın merkezin olanaksızlığı düşüncesi ile yazıyı belli bir merkeze bağlı olarak okumak imkansızlaşmıştır. Derrida ile daha belirgin hale gelen bu düşünce, merkezin olmayışını ve anlamın sürekli ertelendiğini ifade eder. Göstergelerin formuna bağlı olarak anlam sürekli değişir. Sonuç olarak metnin anlamı belirli ve sabit bir şey olarak değil, okurun yorumuna bağlı olarak değişen, belirsiz, çelişkili ve merkezi olmayan bir süreç olarak algılanmalıdır.

\section{Michel Foucault ve Yazarın İşlevi}

Fransız filozof Michel Foucault (1926-1984), "Yazar Nedir?" adlı makalesinde 'söylem'in kökünde yatan bilgi ve düşünceye, modernizmden farklı olarak, tarihsel, kültürel ve ideolojik bir tavırla yaklaşarak, söylem sözcüğünü ele almıştır. Foucault bu yazısında görüşlerini Samuel Beckett'in "Kimin konuştuğunun ne önemi var?” sorusu etrafında geliştirip sergiler. O, bu soruya vurgu yaparak, ortada yazılı bir metin varsa bunun kimin tarafından, neden ve nasıl söylendiğinin önemi konusunu, batı kültür tarihi bağlamında ele almış, yazar isminin ve kavramının toplum içindeki önemi, yeri ve bu kavramın değişik dönemlerde nasıl tanımlandığı üzerinde durmuştur. Eski Yunan ve Ortadoğu toplumlarında yazının ölüm ve yaşamla ilişkili olduğundan, anlatının kimin tarafından gerçekleştirildiğinin bir önemi olmadığından söz etmiştir. Örnek olarak da Homeros destanlarıyla Binbir Gece Masalları'nı vermiştir (Foucault 2006: 229). Bu destan ve masallarda anlatıcının bir önemi yoktur, önemli olan anlatının eski oluşudur. Bu metinlerin eski oluşu doğruluklarının da ölçütüdür. Ancak bu dönemlerde, tıp, doğa bilimleri, astronomi gibi bilimsel metinlerin yazarının kim olduğu çok önemlidir. Bu dönemlerde yazarının adı belli olan bir bilimsel öneri kabul görmüş ve önerinin doğruluğu da o yazarın toplumdaki yerine göre belirlenmiştir (Doltaş 1999: 74). 
Foucault bu yazısında, yazarın adının bir özel isim olduğunu, özel adın ve yazar adının belirtici olmaktan başka işlevleri olduğunu ve belli ölçüler içerisinde bir betimlemenin dengi olduğunu söylemiştir (Foucault 2006: 233). Yazar adı ilk bakışta diğer isimler gibi bir kimliği tanımlarmış gibi görünse de beraberinde bir takım problemleri de getirir. Foucault'ya göre herhangi birini imleyen özel ismin kullanılışıyla bir yazara ait olan özel ismin kullanılışı arasında büyük fark vardır. Yazar olmayan bir kişinin adı kullanıldığında o ad yoluyla o kişinin kişilik özellikleri belirlenmek istenir. Yazar olan kişinin adı, kişiliğiyle değil de yazarlığıyla ilgili kullanıldığında ise o ad yazın söyleminin bir parçası olur ve sınıflandırıcı bir işlev görür (Doltaş 1999: 75). "Yazar adının işlevi belli bir söylem kipini nitelemek olur: Bir söylemin bir yazar adına sahip olması, 'bunu falanca yazdı' ya da 'bunun yazarı şu' diyebilmek, bu söylemin gündelik, alakasız bir söz, çekip giden, yüzen ve geçen bir söz olmadığı, acilen tüketilebilir bir söz olmadığı, belli bir kipte algılanması gereken ve verili bir kültürün içinde, bellli bir statü edinebilecek bir söz olduğudur" (Foucault 2006: 234).

Buna göre yazarın adı metnin varlık tarzını gösteren ve onu karakterize eden bir unsurdur. Yazar adı, belli bir söylemler bütününün oluşmasını gösterir ve bir toplum ve kültür içinde bu söylemin statüsüne gönderme yapar. Bizimki gibi uygarlıklarda, 'yazar işlevine' sahip belli söylemlerin var olduğu, başka söylemlerde ise bunun yer almadı̆̆ söylenebilir. Şöyle ki, özel bir mektubu imzalayan biri vardır ama onun yazarı yoktur, bir sözleşmenin kefili varken, yazarı yoktur, sokaktaki bir duvar yazısını yazan biri vardır ama yazarı yoktur (Foucault 2006: 235). Dolayısıyla Foucault için yazar işlevi, toplumların ve kültürlerin içindeki bir takım söylemlerin varoluş ve işleyişinin bir özelliğidir.

Bununla birlikte Foucault yazar işlevinin bütün söylemler üzerinde evrensel ve değişmez bir biçimde uygulanamadığını belirtir. Bugün hikâye, masal, destan, trajedi, komedi gibi edebi türden saydığımız metinlerin, yazarlarının kim olduğu sorulmadan kabul edildiği, değer gördüğü, onların anonimliklerinin sorun yaratmadığı bir dönem olmuştur. Buna karşın, şu an bilimsel olarak saydığımız, kozmolojik, tıbbi, doğa bilimsel veya coğrafya ile ilgili metinler, ancak bir yazar adına sahip olmaları 
durumunda kabul ediliyordu. 17. ve 18. yüzyıla gelindiğinde ise, bu durum değişmiş, bilimsel söylemlerde yazarın kimliği önemini yitirmiş ve bu metinlerde yazar işlevi artık belirleyici bir rol oynamamaya başlamıştır. Bu dönemde yazar adı belki bir teorem, önerme, önemli bir sonuç ya da bir elementler bütününe bir isim vermeye yaramıştır. Edebi söylemler ise ancak yazarlık işlevine sahip olurlarsa bir değer kazanır hale gelmiştir. Her şiir ya da edebi metnin kaynağının ne olduğu, ne zaman, kim tarafından ve hangi koşullarda yazıldığı gibi unsurlar önem kazanmaya başlamıştır. Bu metinlerin anlamı bu unsurlar bağlamında ortaya çıkmaktadır (Foucault 2006: 237). Sonuç olarak günümüzde edebi eserleri anlamak için yazar(1n) işlevi son derece önemli bir unsur haline gelmiştir.

Foucault, Aziz Jerome'un, kutsal metinlerin yorumlanması için ölçüt olarak verdiği kriterlerin, yazarın işlevi bağlamında modern yazın yorumlamalarında da kullanıldığını belirtir. Bu kriterler şunları içerir: Yazar hem bir metindeki kimi olayların varlığını hem de onların çeşitli dönüşümlerini ve değişimlerini açıklamayı sağlayan şeydir. Yazara ait metni yorumlarken, onun yaşam öyküsünü, kişisel bakış açısını, toplumdaki konumunu ve temel amacını da irdelemek gerekir. Yazar yazıdaki birliğin ve bütünselliğin ilkesidir. Yine yazar, bir dizi metin içinde kendini gösteren çelişkileri aşmayı sağlayan şeydir. Çelişkilerin kaynağı, yazarın düşüncesi ya da arzusuna, bilincinde ya da bilinçdışında olup olmamasına bağlanır. Yazar; az çok tamamlanmış biçimler altında eserlerde, müsveddelerde, fragmanlarda ve mektuplarda kendini anlatan ve gösteren belli bir ifade odağıdır. Foucault'ya göre, günümüz yorumcularına çok yetersiz görünen bu kriterler, modernist yorumcular tarafından kullanılan ve yazarişlevini belirleyen ölçütlere denk düşmektedir (2006: 238- 239).

Foucault, artık söylemleri onların anlatım değerleri ya da biçimsel dönüşümlerine göre değil, varoluş tarzları içerisinde ele almak gerektiğini düşünür. Söylemlerin dolaşım, değer kazanma, atıf ve sahiplenme tarzları her kültürle birlikte değişir ve aynı kültürün içinde de dönüşüm geçirerek farklılaşır. Ona göre, söylemlerin toplumsal ilişkilere göre kazandığı anlam ve ifade ediliş tarzı; söylemlerin ortaya koyduğu tema ya da kavramlardansa, yazar işlevi ve onun değişimleri aracılığıyla daha iyi anlaşılır (2006: 
247). Böyle bir analiz türünden yola çıkmak, öznenin ayrıcalıkları meselesini, öznenin mutlak karakterini ve kurucu rolünü de yeniden incelemeyi gerektirir. Böyle bir inceleme ona göre geleneksel sorunu tersine çevirmek anlamına gelir. Artık sorulan sorular "öznenin özgürlüğü şeylerin özüne nasıl dahil olup onlara bir anlam verebilir? Bir dilin kurallarını içerden nasıl harekete geçirebilir ve nasıl ona özgü fikirler geliştirebilir?" olmayıp, tam tersine "Söylemlerin düzeni içinde özneye benzer bir şey nasıl, hangi koşullara göre ve hangi biçimlerde ortaya çıkabilir? Her söylem türünde hangi yeri işgal edebilir, hangi kurallara uyarak, hangi işlevleri yerine getirebilir?” şeklinde ortaya çıkacaktır. Kısacası, artık önem arz eden şey, özneden ya da onun yerine geçenden kökensel temel olma rolünü almak ve özneyi söylemin değişken ve karmaşık bir işlevi olarak incelemektir (Foucault 2006: 248). Foucault'nun özneye ilişkin bu değerlendirmeleri ile özne söylemi oluşturan bir öğe olmasının yanı sıra, söylem aracılığıyla kendisini oluşturan bir öğe olarak anlaşılır.

Sonuç olarak Foucault bize geleneksel anlamdaki yazar fikrini alt üst etmeyi öğütler. Modernist düşüncede anlam bakımından dünyayı sonsuz bir zenginlik içine yerleştirdiği bir eserin yaratıcı gücü olarak görülen yazar, tüm diğer insanlardan farklı ve tüm dillerden aşkın biri olarak yansıtılmıştır. Oysa yazar bir eseri dolduran anlamların belirsiz bir kaynağı değildir, yazar eserlerinden önce yoktur. Yazar, sınırlandırmaya, dışlamaya ve ayıklama yapmaya yarayan işlevsel bir ilkedir. Foucault yazarın anlam çoğalmasının yok edilmesini sağlayan ideolojik bir ürün olduğunu söyleyerek yazısını sonlandırır (2006: 249). Ona göre yazarı bir deha olarak sunma eğilimi, onu ters bir momentte algılamış olmaktan kaynaklanır. Değişen, dönüşen ve çok anlamlılığın esas olduğu bir dünyada, artık sadece yazara vurgu yapan anlayış yok olmaya mahkum olacaktır.

\section{Sonuç}

Hem Barthes hem de Foucault ele alınan çalışmalarında, Batı kültürü ile özdeşleşen ve eserin anlamını yazarın niyetine bağlayan düşünceyi eleştirmiş, böylece yazarın metindeki geleneksel rolünü tartışmaya açmışlardır. Bu filozoflar aracılığıyla 
modernizmin bir söylemi olan metnin anlamının yazarın yaşamına, eserlerine ve amacına bağlı olduğu düşüncesi kırılmaya başlamıştır. Foucault ve Barthes'ın düşünceleri bizleri yazarlığı, metinselliği, yazarın otoritesini, sanatı ve sanatçıyı nasıl algıladığımıza ve yorumladığımıza yönelik bir sorgulama yapmaya sevk eder. İkisi de edebi yapıtlardaki yazar-okur ilişkisini tartışarak, yazarların ve sanatçıların eserlerindeki ayrıcalıklı konumun sorgulanmasına olanak tanımıştır.

Postmodern yazarların en belirgin özelliği suskunluk yoluyla okurlarına ulaşmak istemeleridir. Suskunluk bir yazın metninde anlam çokluğunu olduğu kadar anlam boşluğunu da aktarabilir. Modernist yazınlarda suskunluğa pek yer verilmez. İnsanın ve evrenin Tanrı tarafından yaratıldığının hakim olduğu batı düşüncesinde, insan kesin ve durağan bir dünyada yaşar. Bu düşüncede sanatçı, anlamsız ve değişken görüntülerin ardındaki gerçeği gören kişi olarak tanınır. Sanatçı ileriyi görme, görünenin ardındaki değişmeyen gerçeği anlama ve yansıtma gücüne sahiptir. Doğal olarak sanatçıyı bu şekilde tanımlayan 18. yüzyıl modernist yazınlarda suskunluğa yer yoktur. Durağan ve evrensel bir gerçek anlayışının çözülmeye başladığı 20. yüzyılda, ekonomik, politik ve kültürel yapının değişmesiyle birlikte, artık evrensel gerçekler değil, insan ve toplum gerçeğinin göreceliliği, değişkenliği ve çok boyutluluğu vurgulanmaya başlamıştır. Bu dönemde yazarlar, gerçeğin kişilere ve ortama göre değiştiğini, kişisel gerçeğin genellikle insanın yapısı ve özgeçmişine bağımlı olduğunu dile getirirler (Doltaş 1999: 105-106). Postmodern yazarlar için suskunluk ya da metin içi boşluklar, okurların veya sanat eserini alımlayan kişilerin birbirinden farklı ve çeşitli yorumları ile doldurulacağından, çokanlamlılığa olanak sağlayan bir unsur olarak görülür.

Modern düşünce ile postmodern düşüncenin sanatçıya ve yazara bakışı farklıdır. Modern düşünce; özne ile nesne, kişi ile toplum, sanat ürünleri ile sanatsal olmayan ürünler arasına kesin sınırlar çizerken, postmodernizm her türlü sınırlandırmaya karşı çıkar. Bunun sonucunda modern sanat evrensel olma iddiası taşırken, postmodern sanat, her türlü sınıflandırmaya karşı olduğundan, sanatsal etkinliğin çeşitliliğini ve tekilliğini savunur. Modern sanatçılar genel olarak 'sanat için sanat' fikri ile özdeşleşerek sanatçının bireyselliğine önem verirler ve bir sanatsal ilerlemeye inanırlar. 
Postmodernizm, modernizmin bütün alanlardaki sınırlandırıcı içeriğine ve sanatsal gelişime olan inancına bir tepki olarak ortaya çıktığından, postmodern sanatçılar, sanat eserlerinde saf bir anlam bulunduğu görüşünü kabul etmezler. Foucault ve Barthes'ın görüşleri öncülüğünde postmodernistler, sanat eserlerini belirli bir zaman ve mekan içine sıkıştırarak, o eseri sadece yaratan kişinin düşünceleri bağlamında algılamayıp, sanatsal anlamı çeşitli yorumların iç içe olduğu bir alana taşımışlardır. Postmodernizmin bu düşüncesi, sanat dünyası ile toplum içindeki hiyerarşileri yıkarak, yazarın ve sanatçının sanat yapıtındaki tek merci olduğu düşüncesini ortadan kaldırmış, metinlerarasılık anlayışını getirmiştir. Postmodern sanatı modern sanattan ayıran önemli bir nokta da, postmodernizmin sanatçı ya da sanat eserinden çok, o eseri alımlayan kişileri ve onların yorumlarını ön plana çıkarmasıdır. Postmodern sanatta sanat eserinin ilettiği bir mesaj olmadığından, alımlayıcı eserden farklı mesajlar çıkarabilir. Böylece sanat eserinin yorumlanmasında yazardan ve sanatçıdan çok alımlayan ve izleyene vurgu yapan postmodernizm, hiçbir eserin kalıcı ve tek bir anlamının olmayacağ fikrini savunarak, modernizmin tersine bir çokanlamlılığın ortaya çıkmasına vesile olmuştur.

Modern düşünce sisteminin dünyayı, insanı ve yaşamı akıl yoluyla tanımlamaya çalışan sınırlandırıcı tavrı karşısında, postmodern düşünce insanın ve yaşadığı dünyanın sadece akıl ekseninde anlaşılmayacağını savunmuştur. Postmodernistler öznenin sürekli bir değişim içinde olduğunu ve onun kendine özgü kalıcı ve sabit bir niteliği olmadığını söyleyerek, sanat eserindeki anlamın sadece sanatçıya veya yazara bağlı olmadığını, anlamın okura veya alımlayana bağlı olarak değiştiğini ve bir çokanlamlılık içerdiğini iddia etmişlerdir. 


\section{KAYNAKÇA}

ARISTOTELES (2017). Poetika Şiir Sanatı Üzerine, çev. Furkan Akderin, İstanbul: Say Yayınları.

BARTHES, Roland (1977). "The Death of the Author", Image-Music-Text, tr. Stephen Heath, London: Fontana Press, 142-148.

BOZKURT, Nejat (2014). Sanat ve Estetik Kuramlarl, Bursa: Sentez Yayıncılık.

CASSIRER, Ernst (1996). Kant'ın Yaşamı ve Öğretisi, çev. Doğan Özlem, İstanbul: İnkilâp Kitabevi.

CROCE, Benedetto (2009). "Sanat Nedir?", Sanatın Felsefesi Felsefenin Sanatı, haz. Mehmet Yılmaz, çev: Nazım Özüaydın, Ankara: Ütopya Yayınevi, 37-47.

CULLER, Jonathan (2008). Barthes, çev. Hakan Gür, Ankara: Dost Yayınevi.

DERRIDA, Jacques, (1981). Dissemination, tr. Barbara Johnson, London: Athlone Press.

DOLTAŞ, Dilek (1999). Postmodernizm Tartışmalar ve Uygulamalar, İstanbul: Telos Yayıncilik.

FOUCAULT, Michel (2006). "Yazar Nedir?”, Sonsuza Giden Dil, Seçme yazılar:6, haz. F. Keskin, Ö. Albayrak, çev. Işık Ergüden, İstanbul: Ayrıntı Yayınları, 224-259.

HEIDEGGER, Martin (2007). Sanat Eserinin Kökeni, çev. Fatih Tepebaş1l, Ankara: De Ki Basım Yayım.

HITCHCOCK, Louise A. (2013). Kuramlar ve Kuramcılar, çev. Seda Pekşen, İstanbul: İletişim Yayınları.

KANT, Immanuel (2006). Yarglyetisinin Eleştirisi, çev. Aziz Yardımlı, İstanbul: İdea Yayınevi. Yayıncilık.

NIETZSCHE, Friedrich (2002). Güç İstenci, çev. Sedat Umran, İstanbul: Birey

ÖZLEM, Doğan (2007). Hermeneutik ve Şiir Sanat,, İstanbul: Şiirden Yayınc1lık.

PETERS, Francis E. (2004). Antik Yunan Felsefesi Terimleri Sözlüğü, İstanbul: Paradigma Yayınları. Yayınlar.

PLATON, (2000). Symposion (Şölen), çev. Cenap Karakaya, İstanbul: Sosyal

SCHELling, (2016). "Sanat”, Plastik Sanatlar, Güzellik ve Doğa, çev. Atilla Erol, İstanbul: Janus Yayıncılık, 57-68.

TUNALI İsmail, (2004). Grek Estetik'i, İstanbul: Remzi Kitabevi. 